NBER WORKING PAPER SERIES

\author{
CHANGES IN THE STRUCTURE \\ OF FAMILY INCOME INEQUALITY \\ IN THE UNTTED STATES AND \\ OTHER INDUSTRIAL NATIONS \\ DURING THE 1980S
}

\author{
McKinley L. Blackburn \\ David E. Bloom
}

Working Paper No. 4754

\author{
NATIONAL BUREAU OF ECONOMIC RESEARCH \\ 1050 Massachusetts Avenue \\ Cambridge, MA 02138 \\ May 1994
}

This paper was prepared while the authors were visiting scholars at the Russell Sage Foundation. They wish to thank Tony Atkinson and Sol Polachek for helpful comments. Melissa Binder and John Higgins provided excellent research assistance. This paper is part of NBER's research program in Labor Studies. Any opinions expressed are those of the authors and not those of the National Bureau of Economic Research. 


\title{
CHANGES IN THE STRUCTURE \\ OF FAMILY INCOME DNEQUALITY \\ IN THE UNITED STATES AND \\ OTHER INDUSTRIAL NATIONS \\ DURING THE 1980S
}

\begin{abstract}
We examine the detailed structure of family income inequality in the United States, Canada, and Australia at various points during the 1980s. In each of these countries we find that income inequality increased among married couple families and that the increases are closely associated with increases in the inequality of husbands' earnings. However, only in the United States is the increased inequality of husbands' earnings also associated with an increase in education-earnings differentials. In addition, increased earnings inequality is associated with increases in both the variance of wages and the variance of labor supply in the United States and Canada, but only with an increase in the variance of labor supply in Australia. Evidence of an increase in married-couple income inequality is also found for France and the United Kingdom, but not for Sweden or the Netherlands.

For married couple families in Canada, Sweden, the United Kingdom, and the United States, we find that increased inequality of family income is closely associated with an increased correlation between husbands' and wives' eamings. A more detailed examination of this correlation in Canada and the United States suggests that the increase in this correlation cannot be explained by an increase in the similarity of husbands' and wives' observable labor market characteristics in either country. Rather, it is explained partly by changes in the way those characteristics translate into labor market outcomes and, more important, by changes in the interspousal correlation between unobservable factors that influence labor market outcomes.
\end{abstract}

McKinley L. Blackburn Department of Economics University of South Carolina

Columbia, SC 29208
David E. Bloom

Department of Economics

Columbia University

New York, NY 10027

and NBER 
Family Income Inequality in the United States Increased during the 1980 s. This fact, whose robustness with respect to a wide range of measurement strategies and techniques has been amply demonstrated (see, for example, Blackburn and Bloom 1987; Karoly 1993), has recelved considerable popular attention in recent years. Discussion of whether increased dispersion in the distribution of family income reflects fundamental changes In the distribution of economic opportunities, changes in family structure and the economic behavior of family members, or more temporary shifts, such as those that might be associated with business cycle fluctuations and changing patterns of forelgn trade, has been especially fertile ground for popular analysis and comentary.

Another well-established fact is that the recent increase in family Income inequality has been closely paralleled by a corresponding increase in the inequality of annual earnings, especially among men (see Blackburn and Bloom 1987; Burtless 1990; Karoly 1993). Although economists have yet to agree on a full explanation for this increase in earnings inequality. Investigators have shown it to be connected with a sizable widening of wage differentials among workers with different levels of educational attainment and labor market experlence (see, for example, Blackburn 1990; Juhn, Murphy, and Pierce 1993). Recent research has also documented empirically several links between the widening of these differentials and shifts that have occurred in variables that affect labor market outcomes, such as union density, the distribution of employment across sectors, and patterns of educational attalnment (see Blackburn, Bloom, and Freeman 1990, 1993; Bound and Johnson 1992; Katz and Revenga 1989; Murphy and Welch 1988).

Increased wage Inequality measured across individuals may not provide a complete explanation for increased income inequality measured across familles. 
Indeed, desplte its seeming simplicity, family income is a relatively complex economic variable that depends only in part upon Individual wages. Family Income can Include the earnings of more than one famlly member, and can also Include Income that is not earned, for example, transfer payments and asset income. In addition, Individuals' total earnings are determined not just by their earnings per hour, but also by the number of hours they work. Thus. In proceeding from the study of Individual wage Inequality - which has a strong theoretical and empirical foundation in labor economics - to the study of family Income Inequality, one is necessarlly led to consider theorles of family formation and family labor supply. Although we have not attempted to develop and estimate a structural model of total family income that is compatible with all these bodles of economic theory, they will gulde and enrich the structure of several of the empirical analyses we report below.

The first objective of this paper is to deepen our understanding of the Increase in famlly Income Inequality that occurred in the United States during the 1980s. We do this by exploring the structure of famlly income inequality, with an emphasis on Identifying how that structure may have changed during the 1980s. In particular, we analyze famlly income on a source-by-source basis, focusing on the varlablilty and relative magnitude of different income sources, and the correlations between the magnitudes of those sources. Our attention is restricted to families headed by married couples with a prime-aged husband, a population that the research 11terature has accorded much less attention than it has female-headed famllies with children or families headed by elderly individuals. Our analysis permits us to consider whether the Increase in income Inequality among married couples that occurred In the 1980 s in the United states reflects, among other things, changes in the distribution of outcomes in the labor market, changes in the labor supply 
behavior of husbands and wives, or an increase in the similarity of husbands' and wives' labor market outcomes.

One of the key empirical results that emerges from our analysis is that Increased Income Inequality in the United States in the $1980 \mathrm{~s}$ is associated with a sizable increase in the correlation between husbands' and wives' earnings. We take this finding as the jumping-off point for a further analysis in which we seek to identify the roots of this change. For this analysis we focus on the correlation of the natural logarithm of earnings across spouses. Given that this correlation can Increase because of an Increase in the correlation of husbands' and wives' characteristics that determine wages earried and hours worked, or because of changes in the regression welghts assoclated with those characteristics, we also fit and analyze some simple wage and hours equations for husbands and wives.

The final objective of this paper is to measure income inequality among married couples in several other Industrial countries at different points in the 1980 s and to explore the nature and stab111ty of the economic structure generating inequality in those countries. By means of this analysis, we hope to determine whether Increased income Inequality among married couples is primarily a United States phenomenon. We also hope to make and interpret cross-country comparisons of changes that have occurred in the structure of family income Inequality.

We also performed detalled analyses of the married-couple Income distributions for Canada and Austral1a. We were able to obtaln appropriate microdata for both these countries that would allow us to study how the structural components of income inequality changed in these countries in the early 1980s. We also present results for four European countries - France, the Netherlands, Sweden, and the United KIngdom - using data from the 
Luxembourg Income Study (LIS). Unfortunately, the lack of Information on labor supply in these data keeps us from performing the same type of analysis of earnings Inequality as we are able to perform for Australla, Canada, and the United States.

Although we offer limited evidence on the extent to which the Australla, Canada, and the Unlted States are representative of a broader set of Industrial countries with respect to the substantive matters under study, we do think these countries provide the basls for some interesting comparisons. For example, all three countrles experlenced net employment shifts during the 1980 s from goods production to service Industries. In addition, male labor force particlpation declined slightly in all three countrles, while female labor force participation Increased. Marriage and fertility rates also declined in all these countries during the 1980s. However, the national unemployment rate decreased in the United States, but Increased in the other two countries. Also, unton density was conslderably lower and declined at a much faster pace in the Unlted states than In Canada and Australia throughout the 1980s. Finally, changes in real government expenditures on welfare and soctal security varled widely among the countries on a per caplta basis. Thus, there seems to be enough (but not too much) diversity among the three countries to suggest that cross-national comparisons might shed some light on the Importance of different economlc clrcumstances and Institutions In the determination of Income Inequality. Unfortunately, the data sets we analyze are generally not sufficlently comparable to Justify making cross-national Inequality comparisons at a polnt in time. However, we do feel comfortable comparing countries in terms of changes in inequallty, because the data sets for each country are comparable over time. 


\section{The Income Source Composition of Family Income Inequality}

Several recent studies of income dispersion In the United states have focused on the distribution of income across families. This literature generally defines the family to be a unit that consists of two or more persons related by blood or marriage who live together. Some studies also include unrelated Individuals - Individuals living alone or with other individuals to whom they are not related - as separate family units (see, for example, Blackburn and Bloom 1987; Karoly 1993). In this paper we analyze only familles headed by married couples. Hence, our results pertain to only a segment of either definition of the total population of families. This restriction facilitates our decomposition of Income Inequality Into contributions from various sources of income, which helps us in investigating the influence of the growth in two-earner couples on overall income Inequality. The pattern of change in Inequality over the period we are considering is reasonably similar for all families and for married-couple families in the three countries we examine. 1

Table 1 presents three measures of total income inequality among married couple families in the United States and Canada in 1979 and 1987 , and in Austral1a in 1981/82 and 1985/86. The samples used for this and later tables are restricted to married couples with husbands between the ages of 25 and 64 . As a general rule, the comparability of these measures across countries at a point in time is questionable, so we limit our comparisons to changes in these measures of dispersion over time. ${ }^{2}$ The results for the United States and

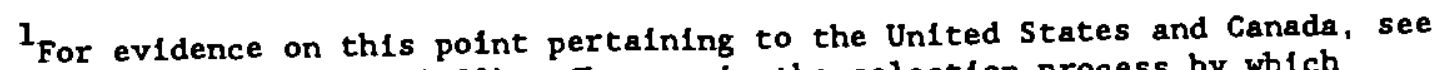
Blackburn and Bloom (1993). Changes in the selection process by which individuals enter the married state may, of course, be responsible for increases in inequality, but we do not examine this possibility here. ${ }^{2}$ As the manner of collection and the quality of the data appear very similar 
Australia show increases in dispersion in the early 1980 s using all the three measures. For Canada, the mean logarithmic deviation falls slightly, Theil's entropy measure increases slightly (but less than this index increased in the United States), and the squared coefficlent of variation increases modestly, but less than the Increase observed in the United States. ${ }^{3}$

Table 1 contains two estimates of the squared coefficlent of variation for Australia. The first estimate (and the MDD and ENT) was calculated using a measure of total family income that does not include interest and dividend income. We excluded this income source because the process by which it was collected changed dramatically from $1981 / 82$ to $1985 / 86$. Using a decomposition property of the squared coefficient of variation (discussed below), we also calculated an inequality measure that included interest and dividend income (reported in parentheses in the table). In this calculation, we used the parameters characterlzing the distribution of interest and dividend income in $1985 / 86$ for both $1981 / 82$ and $1985 / 86$, thereby allowing the relative importance of this source to change as it did in the national income accounts of Australia ${ }^{4}$. The increase in inequality measured this way is similar to the

for the United States and Canadian surveys, meaningful Inequality comparisons between these two countries at a point in time may be possible. The data used for these calculations are discussed later in this section, with further detalls reported in appendix $A$.

${ }^{3}$ The fact that the mean logarithmic deviation did not increase in Canada, but the entropy and squared coefficient of variation did, reflects the property that the mean logarithmic deviation is relatively more sensitive to changes at the lower end of the distribution (and the lowest quintile in Canada experfenced an increase in 1ts total share of income over this perlod), while the squared coefficlent of variation is more sensitive to changes at the upper end (where changes were occurring so as to increase inequallty in Canada). ${ }^{4}$ The major effect of the change in collection procedures was to increase (from 0.04 to 0.07 ) the percentage of famlly. Income that was due to interest and dividend income, and perhaps to increase the measured inequality of interest and dividend income. In the national income accounts, the share of income from interest and dividends increased only slightly during this perlod. As 
Increase observed when excluding interest and dividend income. In the analysis of the squared coefficient of variation that follows, we will continue to use this procedure for the Australian data.

Given that family income is composed of income from several different sources, a natural question is whether the increases in famlly income Inequality reported in table 1 can be linked to increases in the inequality of one or more income sources or to some other underlying change in the distribution of family income. In particular, we wish to explore whether observed increases in earnings inequality among husbands (and possibly wives) can account for all the increases in family income inequality in table 1 , or whether some other factor might also be partly responsible for the increases.

Following earlier analyses of the distribution of family income (Gronau 1982; Lehrer and Nerlove 1984; Schirm 1988; Smlth 1979), we focus on the squared coefficlent of variation as our measure of dispersion. Dividing a family's income into $J$ different sources, the squared coefficient of variation - which is simply the ratio of the variance of income to the square of its arithmetic mean - can be written as:

$$
c v^{2}-\underset{j-1}{J} s_{j}^{2} c v_{j}^{2}+2 \underset{j-1}{\Sigma} \underset{k-j+1}{\Sigma} s_{j} s_{k} C v_{j} C v_{k} p_{j k}
$$

where $s_{j}$ is the share of total income coming from the $j$ th source, $c v_{j}^{2}$ is the squared coefficient of variation for the $j$ th source, and $\rho_{j k}$ is the correlation coefficient between the $j$ th and $k$ th income sources. Unlike logarithmic-based measures of dispersion, the squared coefficient of variation

the change in procedures should have produced more accurate measures of this income source, we chose to use the $1985 / 86$ parameters in recalculating the squared coefficlent of variation. 
is defined for zero incomes. While there may be zero amounts for many sources of Income, equation (1) still holds as long as the $\mathrm{CV}_{\mathrm{j}} \mathrm{s}$ are calculated using the zeros. 5

Equation (1) provides few general prodictions about how overall income Inequality $\left(C \mathrm{CV}^{2}\right)$ can be expected to change given changes in the shares, the $\mathrm{CV}_{\mathrm{f}}^{2} \mathrm{~s}$, or the correlation coefficlents (see Schirm 1988). The only prediction that does not depend on values of the other parameters is the following: If the correlation coefficlent between two sources of income Increases, then $C V^{2}$ will increase. $C V^{2}$ will also increase when $C V_{j}^{2}$ increases provided that all correlation coefficlents involving the $j$ th source of income are positive (this condition is sufficient, but not necessary). The effects of changes in the shares of the income sources are generally unclear. For example, if the share of the $j$ th Income source Increases and the share of the kth source falls by the same amount, then the direction of the change in $\mathrm{CV}^{2}$ will depend on the relative sizes of $\mathrm{CV}_{j}^{2}$ and $\mathrm{CV}_{\mathrm{k}}^{2}$, as well as of all other shares, coefficlents of variation, and correlation coefficlents.

While predicting how changes in the income source coefficlents of variation or shares will affect overall inequality is difficult, a direct estimate of the effect on $\mathrm{CV}^{2}$ of changes in the components of the decomposition in equation (1) for actual or assumed values of the other components is posstble. For example, suppose we wish to estimate how changes In the dispersion of husbands' earnings from 1979 to 1987 affected Income

${ }^{5}$ Other decompositions of $\mathrm{CV}^{2}$ are also possible, for example, $\mathrm{CV}^{2}$ can be expressed as an exact function of the means, varlances, and covarlances of the $\mathrm{J}$ income sources. However, the $C \mathrm{~V}^{2}$ decomposition we use has the attractive property that each of the components of the decomposition are invariant to the scale in which income is measured (as is $\mathrm{CV}^{2}$ itself), while the alternative decomposition does not possess this property. 
inequality. We might estimate this impact by first simulating what $\mathrm{CV}^{2}$ would have been if the inequality of husbands' earnings changed from its observed 1979 level to its observed 1987 level, but all other parameters in the decomposition equation remained at their 1979 values. 6 We can then compare this simulated value to the actual 1979 value, interpreting the difference as the effect of changes in the dispersion of husbands' earnings on total income inequality. 7 Such analyses can be performed for changes in an income source $\mathrm{CV}^{2}$ or changes in a correlation coefficient between income sources; however, since the income source shares must sum to one, a change in any one share must be accompanied by a change in at least one other share.

In the following subsections we analyze the components of changes in married couple income inequality using the $\mathrm{CV}^{2}$ decomposition outlined above for a breakdown based on five Income sources for the United States, Canada, and Australia. The income sources are husbands' earnings, wives' earnings, other earnings, interest and dividend income, and other income (which primarily includes government transfer payments and pension income).

\section{The United States}

Table 2 shows the structure of family income inequality in the United States in 1979 and 1987 . It does this by reporting income shares and squared coefficients of variation for the five income sources, and correlation coefficients between these sources, for the United States in 1979 and 1987.

6his effect can also be estimated using 1987 values of the decomposition equation parameters. As the two estimates will not necessarily be equal, we calculate and report both sets below.

7 Changes in the distribution of one income source may also affect the distribution of other income sources. For example, changes in the inequality of husbands' earnings could affect the distribution of wives' earnings or of other earnings. By itself, the $\mathrm{CV}^{2}$ decomposition provides a simple mechanism to account for changes in income inequality. It does not identify behavioral linkages between different income sources. 
These statistics were calculated using the 1980 and 1988 March Current

Population Surveys, and correspond to reports of annual income in the calendar years preceding each survey.

Several notable changes in the components of famlly income inequality in the United States occurred during this perlod. The $C V^{2}$ for husbands' earnings Increased, while the $\mathrm{CV}^{2}$ for wives' earnings fell. The share of Income made up by husbands' earnings fell by 5 percentage polnts, with the share made up by wives' earnings increasing by the same amount. The major change from 1979 to 1987 in the relationships between income sources was the Increase in the correlation coefficlent between husbands' and wives' earnings from 0.01 to $0.11 .^{8}$

The statistics in table 2 are computed using zero incomes for a particular income source when a famlly recelves no income from that source. This fact Implies that our results for changes in the dispersion of husbands' and wives' earnings may differ from those derived from a sample that is limited to Individuals with positive earnings (as in Blackburn and Bloom 1987; Burtless 1990; Karoly 1993). A major difference between the Inequality statistics reported in table 2 and corresponding statistics reported in earlier research is our finding that the coefficient of varlation of wives' earnings (zeros included) decreased during the 1980s, while earlier research (using positive incomes only) found that earnings inequality among women increased. The decline in earnings inequality among our sample of wives can be entirely attributed to an increase in the percentage of wives with positive

${ }^{8}$ Cancien, Danziger, and Gottschalk (1993) also discovered an Increase in the correlation coefficlent between husbands' and wives' earnings in the United States during the 1980s, although their findings suggest that the increase occurred only among white couples. 
earnings. 9 This increase in wives' employment would also be expected to increase the correlation coefficlent between the earnings of all husbands' and wives', but this change does not account for much of the increase in the correlation coefficient (for example, the interspousal earnings correlation coefficlent among families in which both the husband and wife have positive earnings increased from 0.10 to 0.18 ).

Table 3 presents sumary statistics that relate to our analysis of changes in the level and structure of famlly income inequality from 1979 to 1987. As described earlier, these statistics are calculated by changing selected components in equation (1) from their estimated 1979 value to their estimated $1987^{\prime}$ value, whlle holding all other components fixed at their observed 1979 values. For example, if all components of the decomposition

${ }^{9}$ Let $n, C V^{2}$, and $\bar{y}$ be the population size, squared coefficient of variation, and mean income for the complete population, and let $n_{1}, C v_{1}^{2}$, and $\bar{y}_{1}$ be the same numbers for the subset of the population with positive incomes. Using the additive decomposability property of the squared coefficient of variation (see Bourguignon 1979), we can write $\mathrm{CV}^{2}$ as:

$$
c v^{2}-\left(n_{1} / n\right)\left(\bar{y}_{1} / \bar{y}\right)^{2} c v_{1}^{2}+\left(n_{1} / n\right)\left(1 / \bar{y}^{2}\right)\left(\bar{y}_{1}-\bar{y}\right)^{2}+\left[\left(n-n_{1}\right) / n\right] .
$$

Using the fact that $\bar{y}-\left(n_{1} / n\right) \bar{y}_{1}$, this expression simplifies to:

$$
C v^{2}=\left(1 / p_{1}\right) C v_{1}^{2}+\left(1-p_{1}\right) / p_{1}
$$

where $p_{1}-n_{1} / n$ is the percentage of individuals with positive incomes. Assuming that changes in $p_{1}$ leave $C V_{1}^{2}$ unchanged (that is, that the distribution of earnings among wives entering the labor force is the same as that for wives already in the labor force). It follows that increases in $p_{1}$ lower $C V^{2}$. With $C V_{1}^{2}-.66$ in 1979 in the United States, the Increase in $p_{1}$ from $0.6 \frac{1}{2}$ to 0.69 accounts for all of the fall in the $C V^{2}$ for wives' earnings $\left(C V_{1}^{2}-.66\right.$ in the United States in $\left.1987 \mathrm{also}\right)$. 
stayed constant at their 1979 values except for the squared coefficient of variation for husbands' earnings (which increased from 0.42 to 0.48 ), the overall $\mathrm{CV}^{2}$ would have increased by 0.028 , a magnitude equal to 62 percent of the actual increase in the overall $\mathrm{cv}^{2}$. Similarly, with other parameters held constant, the increase from .01 to .11 in the correlation coefficient between husbands' and wives' earnings would have increased the overall $\mathrm{CV}^{2}$ by 44 percent. The fall in $\mathrm{CV}^{2}$ for wives' earnings accounts for a small decrease in income inequality (although the magnitude is roughly twice as large if 1987 base parameters are used, partly because the share of income from wives' earnings was larger in 1987 than in 1979).

The effect of changes in income shares on inequality is positive but small, especially if 1987 base components are used in the decomposition. Most of the impact appears to be caused by the increased share of income coming from interest and dividend income (and the fall in the share from other earnings), as the size of the effect from shifts in income shares is smaller if only the changes in the shares of husbands' and wives' earnings are considered. ${ }^{10}$ Unfortunately, the magnitude of the income share effects is quite dependent on the values of the other components of the decomposition, so any statements about the effects of shifts in shares are tenuous.

\section{Canada and Australia}

The data on income inequality among Canadian married couple families are drawn from the 1980 and the 1988 survey of Consumer Finances. The top panel of table 4 reports the components of the $C V^{2}$ decomposition for Canada in 1979 and 1987, while the top panel of table 5 reports the sources of change

${ }^{10}$ A rough calculation shows that about half of the increase in the share of income from wives' earnings is caused by higher employment rates for women, with the other half caused by an increase in the wife/husband earnings ratio. 
accounting for the measured increase in $\mathrm{CV}^{2}$. For the most part, the structure Income Inequal1ty, and the changes in that structure from 1979 to 1987, are similar In Canada and the United States. In Canada, the two major forces leading to Increases in famlly income Inequality are an Increased dispersion of husbands' earnings and an Increased Interspousal correlation of earnings. The fall in the $\mathrm{CV}^{2}$ of wives' earnings - caused completely by Increased employment probabilities, as in the United States - offset these two forces to some extent. In addition, the change in income shares also suggests a decline in Income Inequality in Canada, largely because of the Increased share coming from government transfers. Th1s was not the case in the United States (see Blackburn and Bloom 1993). 11

The Australian statistics were computed using the 1981/82 Income and Housing Survey and the 1985/86 Income Distribution Survey. The results are presented in the lower panels of tables 4 and 5 . The increase in the Inequality of husbands' earnings is clearly the dominant factor associated with the increase in overall famlly income inequal1ty in Austral1a. The change in the correlation coefficlent between husbands' and wives' earnings is much smaller In Australla than In the UnIted States or Canada, and plays a small role in increasing inequal1ty. Changes in Income shares had a large effect in decreasing overall inequality, again largely because of the Increase In the Importance of other Income.

other Countries and Tlme Perjods

We also computed the components of the $\mathrm{CV}^{2}$ decomposition for married couples in the United States in 1991 using data from the March 1992 Current

\footnotetext{
11 The Inequality of other Income does tend to be relatively high, but its strong negative correlation with husbands' (and wives') earnings leads to increases in its share that generally cause overall inequality to fall.
} 
Population Survey. Selected components are reported in the first row of table 6. The results suggest that the income distribution for married couples changed very 11ttle after 1987, with overall inequality stable between those years. Although, the correlation between husbands' and wives' earnings did not change, both the inequality of husbands' earnings and the share of income made up by wives' earnings increased from 1979 to 1987.12

We also perform the $\mathrm{CV}^{2}$ decomposition for several additional countries using data sets available as part of (LIS). ${ }^{13}$ The LIS income data differ conceptually from the income data we have been using, as LIS researchers have made several adjustments to take noncash benefits into account. 14 Results for four countries 'with LIS data from the late 1970 s to the early 1980 s are presented in table 6 . Overall income inequality among married couples Increased in the early $1980 \mathrm{~s}$ in France and the United Kingdom, but not in Sweden. The Netherlands also did not experience an increase in inequality from 1983 to 1987, although unlike our other comparisons, the Dutch comparison is of a recession year (1983) with a nonrecession year (1987). Changes in husbands' earnings inequality differed considerably across countries, with an especially large Increase for the United Kingdom (even compared to the UnIted States, Canada, and Australia), and again a decline in the Netherlands. All

12 The increase in the inequality of husbands' earnings (perhaps caused by the recession) appears to have been offset by a continued decline in the inequality of wives' earnings.

13 (1990).

${ }^{14}$ The LIS data for the United States, Canada, and Australia are actually drawn from the same household surveys we use. However, the LIS data contain only a randomly sampled fraction of the survey for the United States and Canada. We also performed our decomposition using the LIS data for the United States for 1979 and 1986. While the actual magnitudes of the decompositions are different when compared to table 2, the general pattern of the changes over time are quite similar in the two analyses. 
the countries experienced an Increase in the share of Income from wives' earnings, although this Increase was much larger In Canada and the United States than in the other countries.

Less evidence supports the universality of Increases in the correlation between husbands' and wives' earnings. This correlation Increased in Sweden and the Unlted KIngdom, both for all couples and for two-earner couples, but In France (as In Australia), the Increase was not observed among two-earner couples, and in the Netherlands the correlation coefficlent actually declined for all couples. At least a loose correlation appears to exist betweenchanges In the Interspousal correlation of earnings and increases in husbands' earnings Inequailty; as some evidence of an Increase in both is apparent for every country except the Netherlands, where both fell.

\section{The Relationship between Husbands' and Wives' Earnings}

The results of the previous section point to an increase in the correlation between husbands' and wives' earnings during the 1980 s as an Important factor assoclated with Increases in famlly income Inequality in several countries. The purpose of this section is to examine this result more closely for the United States and Canada, for which we have data on labor supply of Individual family members. In particular, we wish to discover whether the Increased correlation of earnings reflects an increase in the correlation of husbands' and wives' hourly wages or in the number of hours worked. Is it a consequence of changes in the process by which men and women sort themselves into married couple units, so that men with characteristics that tend to be well rewarded in the labor market are more $11 k$ ky to be married to women who also possess such characterlstics? Or have changes in the structure of the relationships between Individual characteristics and 
labor market outcomes led to increases in the correlation of husbands' and wives' earnings?

In this section we focus on the logarithm rather than on the level of earnings to facilitate our analyges. Let $\mathrm{E}_{\mathrm{B}}-\mathrm{W}_{\mathrm{B}} \mathrm{H}_{\mathrm{B}}$ represent annual earnings for husbands, and $E_{W}-W_{H} H_{W}$ annual earnings for wives. The covariance of $10 \mathrm{~g}$ earnings between husbands and wives can be written:

$$
\text { (2) } \begin{aligned}
\operatorname{cov}\left(\ln E_{B}, \ln E_{H}\right)= & \operatorname{cov}\left(\ln w_{B^{\prime}} \ln w_{H}\right)+\operatorname{cov}\left(\ln H_{B}, \ln H_{H}\right) \\
& +\operatorname{cov}\left(\ln w_{B^{\prime}} \ln H_{W}\right)+\operatorname{cov}\left(\ln w_{B^{\prime}}, \ln H_{H}\right) .
\end{aligned}
$$

Wh1le we take note of the changes in the last two terms of equation (2), we focus our attention primarily on changes in the first two terms on the right-hand side of equation (2), the interspousal covariance of log wages and of $\log$ hours. We analyze changes in these two covariances both unconditionally and conditionally on a set of regressors that are fairly standard in the estimation of wage and labor supply equations.

We assume that $\log$ wages $\left(z_{j}\right)$ follow: 15

$$
z_{j}-\beta_{j} x_{j}+\epsilon_{j}, j-B, H
$$

where $x_{j}$ is a vector of observed characteristics, $\beta_{j}$ is a spouse-specific coefficlent vector, and $\epsilon_{j}$ is an error term. We also assume that hours worked by Individuals with positive hours worked follows:

(4) $\operatorname{In} H_{j}=\gamma_{1 j} z_{k}+\gamma_{2 j} z_{H}+\gamma_{3 j} x_{j}+u_{j}, j-z_{, H}$, where the $\gamma_{1 j} s$ are parameters and $u_{j}$ is an error term. Substituting equation (3) Into equation (4) ylelds a reduced-form equation for hours worked:

${ }^{15}$ Family-specific subscripts are suppressed. 
(5) $\ln H_{j}-\pi_{1 j} x_{i}+\pi_{2 j} x_{w}+u k, j-4$.

By estimating equations (3) and (5), we can study the extent to which changes in the correlation of $X_{B}$ and $X_{y}$ or changes in the interspousal correlation of residuals in equations (3) and (5) have affected the correlation of hours and wages between spouses. We also estimate employment probability equations that, like equation (5), follow the form:

(6) $P_{j}=\alpha_{1 j} x_{a}+\alpha_{2 j} x_{k}+\omega_{j}, j-\pi, \omega$,

where $P_{j}$ is an Indicator of an Individual's employment status. Estimates of these equations allow us to study changes in the correlation of employment status between spouses.

Changes over time in the interspousal correlation of wages, hours, or employment can result from changes in the correlations of the systematic or the stochastic components of equations (3), (5), and (6). For instance, the sample Interspousal correlation ( $r$ ) of $\log$ wages can be written:

$$
\text { (7) } \quad r\left(z_{B}, z_{W}\right)=\frac{s_{z_{B}}^{s \hat{z}_{W}}}{s_{z_{B} s_{z_{W}}}} r\left(\hat{z}_{B}, \hat{z}_{W}\right)+\frac{{ }_{\hat{\varepsilon}_{B}}^{s \hat{\varepsilon}_{W}}}{s_{z_{B}} s_{z_{W}}} r\left(\hat{\varepsilon}_{B}, \hat{\varepsilon}_{W}\right)+R \text {. }
$$

where $\hat{z}_{j}-\hat{\beta}_{j} x_{j}$, s is the sample standard devlation of the subscripted vartable, and $R$ is a remalnder term. ${ }^{16}$ From equation (8), the overall correlation coefficient consists partly of a welghted sum of the correlation between the

${ }^{16}$ The remainder consists of welghted correlations between $\hat{z}_{B}$ and $\hat{\varepsilon}_{W}$, and between $\hat{z}_{W}$ and $\hat{\epsilon}_{B}$. In our empirical work, we focus on the correlation between the predicted values and the correlation between the residuals, because the correlations embodied in the remainder term do not lend themselves eas $11 y$ to interpretation. 
husbands' and wives' predicted wages and the correlation between their wage residuals. ${ }^{17}$ similar expressions exist for the hours and employment equations. One hypothesis of interest to us is that changes in the similarity of husbands' and wives' labor market characteristics might be the cause of increases in the correlation of husbands' and wives' earnings. This could be the result, for instance, of technological changes in household production that have reduced the incentive for specialization by husbands and wives. While the periods on which we focus may appear somewhat short, rates of martital formation and dissolution, as well as simple aging, are sufficient to suggest the possibllity of considerable turnover in the husband-wife palrs sampled in our data. 18

We evaluate emplrically how changes in the correlation of observable characteristics have affected the correlation in earnings by measuring the extent to which changes in the distribution of $X_{B}$ and $X_{W}$ in equations (3), (5), and (6) have affected the correlation in the nonrandom components of wages, hours, and employment, that is $r\left(\hat{z}_{B}, \hat{z}_{w}\right)$ in equation (7). It is also true that changes in the stxucture of the relationships between observable characteristics and wages or labor supply can affect the various interspousal correlations (see appendix B). ${ }^{19}$ Thus, we will use equation (7) - applied separately to employment, hours, and wages - to explore whether the

17 The two weights that appear in equation (8) sum to a number less than one. If the two correlations that make up the remainder term had been included, the welghts on the four correlations would sum to one.

18 A

${ }_{A}$ A rough calculation suggests that as much as 50 percent of the married couples eligible for inclusion in our 1979 samples (for the United States and Canada) would be elther ineligible or digsolved in 1987. 19 As shown in appendix $B$, this result holds only in the context of multiple regression equations. In the case of a simple regression, the correlation between the predicted values of spouses' labor market outcomes is simply the interspousal sample correlation of the independent variable. 
correlation between husbands' and wives' earnings Increased during the 1980s because of an increase in the interspousal correlation between measured

factors that determine labor market outcomes, changes in the coefficlent welghts for those measured factors, or changes in the interspousal correlation of the stochastic components of our labor market equations.

The United States

For the U.S. data we define our hours variable as annual hours worked and our wage rate variable as annual earnings divided by annual hours worked. 20 The top panel of table 7 reports the variances of the logarithms of wages and hours and the covarlance between the $\log$ of wages and the $\log$ of hours separately for husbands and wives in 1979 and 1987.21 For husbands both the dispersion of wages and the dispersion of hours increased in the 1980s, while for wives the dispersion of wages increased, but the dispersion of hours fell. The correlation between hours and wages increased slightly for both husbands and wives during this period.

The bottom panel of table 7 reports interspousal correlation coefficients for earnings-related characteristics and for earnings and their components in 1979 and 1987. As with the correlation between the levels of husbands' and wives' earnings, the correlation between the logarithms of husbands' and of

20 Because we restrict our wage-equation sample to working individuals who meet a minimum-1evel wage restriction (see appendix A, 1tem 10), there are somewhat fewer observations for wages than for hours.

${ }^{21}$ These statistics are the components of the decomposition of the variance of logarithms of annual earnings (E-wH) among individuals with positive earnings:

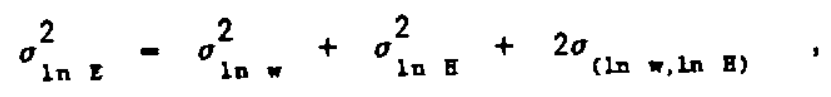

where $\sigma_{(\ln , 1 \mathrm{ln} \text { i) }}$ is the covariance of $\log$ wages and $\log$ hours. 
wives' earnings increased during the perlod. This increase was largely the result of an increase in the interspousal correlation of log wages, as the correlation of $\log$ hours did not change. 22 There was also an Increase in the employment correlation from 1979 to 1987. However, focusing on the Interspousal correlations of earnings-related characteristics, we see no change in the correlation coefficient for education, and a slight decline in the correlation coefficient for age.

Least-squares estimates of reduced-form equations for employment, annual hours worked, and wages are reported for husbands and wives in table $\mathrm{Cl}$ of appendix C. 23 The most notable change from 1979 to 1987 in the coefficlent eatimates for the husbands' equations is the increase in the importance of schooling to wages for both husbands and wives. The age coefficient estimates also changed between years in most equations, revealing an increased tendency for older husbands to work less compared to younger husbands, and for younger husbands and wives to earn relatively lower wages.

Table 8 reports interspousal correlation coefficients of predicted

${ }^{22}$ There was also an increase in $r\left(\ln w_{b}, \ln H_{w}\right)$ from -.08 in 1979 to -.06 in 1987, and $\ln r\left(\ln w_{H}, \ln H_{B}\right)$ from 0 to .04 .

23 The independent variables in these equations include the individual's education, age, region of residence and number of dependents (that is, nonearners) in the family. In the wage equation, education is assumed to onter as a spline function (as in Card and Krueger 1992) with a shift in the slope allowed at elght years of education, while age is entered as a quadratic. As wages enter the employment and hours equations, these specifications for age and education (for both spouses) are preserved in the employment and hours equations for each spouse. Table Cl reports

the coefficient estimates for the husbands' age and education variables in the husbands' labor-market equations, and the coefficients for the wives' age and education variables in the wives' equations.

We also estimated wage and hours equations for wives in which we made standard selectivity corrections for being employed (see Heckman 1979). Our coefficlent estimates were virtually unchanged by this modification, and the estimates of the error covarlance between the wage (or hours) equation and the problt equation were small and insignificant. 
values and of residuals for the employment, hours, and wage equations in 1979 and 1987. The estimates Indicate that the interspousal correlations of predicted hours and wages (and employment) increased from 1979 to 1987. The interspousal correlation of wage residuals also increased from 1979 to 1987. but the correlation of hours residuals declined slightly. Observe that the increase in the correlation between the wage residuals is much more important to the overall increase in the interspousal wage correlation than is the increase in the correlation of predicted wages. This result arises because the residual correlations recelve much greater weight in determining the overall change in the wage correlation, a consequence of the fact that the residual varianices tend to be much larger than the variances of the predicted values (see equation $[B]$ ). This result also explains why the large increase In the interspousal correlation of predicted hours is not associated with an Increase in the observed Interspousal hours correlation.

The stability of the interspousal age and education correlations suggests that the increase in the interspousal predicted value correlations of wages and hours is not caused by changes in the coefficlents in the wage and hours equations. However, as the predicted value correlations do not depend simply on these two correlations of characteristics - because of nonlinearities, the inclusion of other regressors, and so on - we sought to verify this conclusion by recalculating the predicted value correlations for the 1987 sample of married couple families using the 1979 wage and labor supply coefficient estimates. The bottom two rows of table 8 present these alternative correlations. The results indicate that one-third to two-thirds of the increase in the employment and hours predicted-value correlations remain when coefficlents are held at their 1979 values, but that no change occurs in the wage correlations. Hence, the increase in the interspousal wage 
correlation appearg to be entirely caused by changes in the wage equation coefficients and by an increase in the residual correlation, and not by the formation of marital unions that are more homogeneous in terms of wage-related characteristics. By contrast, the increase in the interspousal correlation of hours is caused both by changes in coefficients and changes in the independent variable relationships, which suggests that part of the increase in the correlation of hours may be a result of changes in the homogeneity of marital unions with respect to hours-related characteristics.

\section{Canada and Australla}

Our defintions of employment, hours, and wages are slightly different for Canada and Australia than for the United States because of the nature of the avallable data. For Canada and Australia we use average weekly earnings for workers who usually work full-time as our wage variable, and weeks worked during the year by full-time workers as our labor supply variable. For purposes of constructing an interspousal education correlation, we Imputed a value for years of education using educational codes available in the data. The components of the variance of $10 \mathrm{~g}$ earnings and the interspousal correlations of labor market characteristics and outcomes are reported in table 9. The variance of $\log$ wages for husbands and wives increased in Canada, but changed very little in Austral1a, where the increased dispersion of husbands' earnings (and the decreased dispersion of wives' earnings) is attributable to changes in the variance of labor supply. The Interspousal correlation of education Increased in Australla, but not in Canada, which is a curious result given that the increase in the correlation of earnings and wages was larger in both Canada and the United States.

We repeated our analysis of changes in the hours and wage correlation between spouses for Canada only, because there was little evidence of an 
Increase in the hours and wage correlations in Australla. ${ }^{24}$ Table C2 In appendix $C$ reports the coefflcient estimates for the 1979 and 1987 employment, weeks, and wage equations. The coefflclent estimates for the husbands' equations demonstrate that differences in husbands' labor supply were more closely tied to education in 1979 than in 1987; however, unlike in the United States, wage-schooling relationships remained falrly stable from 1979 to 1987 . In contrast to their husbands, wage differences assoclated with education widened sharply from 1979 to 1987 for Canadlan wives.

The interspousal correlations of predicted values and residuals for the three labor market equations are reported in table 10. The entire increase In the overail 'correlation between spouses in employment, and much of the increase in the correlation in weeks, is a result of increased correlation in the predicted values, However, the interspousal correlation of predicted wages actually fell slightly from 1979 to 1987 . In this case, the increase in the interspousal wage correlation is entirely caused by the increase in the Interspousal correlation of the wage equation residuals. Increases in the predicted value correlations for employment and weeks are malniy because of changes from 1979 to 1987 in the coefficlents for those equations, and not because of changes in the similarity of spouses' labor market characterlstics.

\section{Discussion}

Income Inequality Increased during the 1980s among families headed by a marrled couple in several indugtrial nations. Our results also reveal that the Increase in income inequality among married couple families is closely

${ }^{24}$ The larger size of our Canadian sample also suggests that the wage correlation decomposition is more rellable for Canada than for Australia. 
assoclated with increased earnings inequality among husbands in familles headed by a married couple.

In the United States, the rise In husbands' earnings Inequality is Iinked to the widening of their education-earnings differentials and somewhat less closely to the steepening of their age-earnings profiles. However, these changes only explain a portion of the Increase in husbands" earnings Inequality in the United States. ${ }^{25}$ Changes in education-related earnings differentials were much smaller in Ganada and Australla during the 1980s, and so can explain almost none of those countries' Increases in husbands' earnings Inequality.

Although the 1requality of husbands' earnings increased in Australla, Canada, and the Unfted States, our analyses reveal some striking cross-country differences in the processes generating those increases. For example, among United States and Canadian husbands, Increased earnings Inequality is assoclated with Increases in both the varlance of wages and the varlance of labor supply, but among Australian husbands, increased earnings Inequality is assoclated with an Increase in the variance of labor supply, but not in the varlance of wages (which actually declined slightly between the two survey years).

This pattern of findings lends itseif quite readily to interpretation. During the 1980s, the United States, Canada, and Australla all experlenced a shift in employment from their high-wage industrial sectors to their low-wage service sectors. Industry's share of employment decreased by 4 percentage points In the United States, Canada, and Australla from 1979 to $1987 .{ }^{26}$ Some

${ }^{25}$ See Blackburn (1990) and Juhn, Murphy, and P1erce (1993). ${ }^{26}$ The United Kingdom, which appears to exhlblt even larger Increases in male earnings inequality and education-earnings differentials than the three 
Investigators have argued that these declines relate at least partly to the Increased flow of world trade and to corresponding adjustments in the world division of labor. 27 Some have also argued that changes are taking place in the nature of economic activity within these countries, with industrial production becoming more capital- and technology-intensive, and therefore more sk111-1ntensive (for example, see Leontief 1982). The decline of Industrial employment, the acceleration of technological change, and the escalation of average skill requirements in the industrial sector would be expected to strengthen the relative demand for skilled workers in an economy, thereby possibly contributing to an increase in earnings inequality. 28

However, even if one accepted the view that common forces were acting to Increase the inequality of male earnings and famlly income in the United States, Canada, and Austral1a in the 1980s, why would the effects of these

countrles under study here (see Katz, Loveman, and Blanchflower 1993), also experienced the largest decilne in industry's share of employment from 1979 to 1987 ( 9 percentage points). Japan, by contrast, exhibited a negligible change in manufacturing's share of employment and a very small increase in education-earnings differentials (see Katz and Revenga, 1989).

27 Murphy and Welch (1998) discuss these 1 ssues further and provide evidence related to the United States economy. Alternatively, Baumol, Blackman, and Wolff (1985) argue that a decline in manufacturing's share of employment in an economy is a consequence of inherently faster productivity growth in the manufacturing sector relative to the service sector.

Findlay (1993) constructs a general equilibrlum model in which increased openness of trade can lead to a decrease in the relative demand for less-skilled workers. Bhagwat1 and Dehej1a (1993) argue that recent patterns in U.S. International trade are not consistent with such a decrease, and so do not contribute to the increase in earnings inequality. Their empirical argument is partly based on evidence from changes in the relative prices of 1mported and exported goods.

${ }^{28}$ In the case of the United States, Blackburn (1990) and Juhn, Murphy, and Plerce (1993) provide evidence that sectoral shifts account for a portion of increased male earnings inequality between the late 1960s and the mid-1980s. Kruger (1993) and Mincer (1993) provides evidence that the acceleration of technological change in the 1980 s contributed to the increase of education-earnings differentials in the United states. 
forces manifest themselves so differently across these countrles with respect to the components of husbands' earnings Inequality? One possible explanation relates to differences in the nature of the labor markets in the three countries under study. In particular, wage determination in Australia is fundamentally a centralized and authoritative process, with minimum wage rates for each occupation determined by state and federal wage tribunals. In addition, Australian workers are highly unionized: the unionization rate was 58 percent in 1980 and 56 percent In 1987. By comparison, wage determination Is relatively decentralized and unregulated in the United States and Canadian labor markets. In addition, relative to Australia, the unionization rate was low in Canada in the 1980 s (36 percent in both 1979 and 1987) and even lower In the United States (25 percent in 1979 and 17 percent in 1987). Minimum wages also fell sharply in real terms in the Unlted states during the 1980 , diminishing any relevance they may have had to the determination of labor market outcomes for prime-age men.

In line with these differences in the nature of each countrles' labor market Institutions, our results suggest that market forces play a weaker role In wage determination In Australia than in the United states or Canada. The variance of husbands' earnings increased in Australla not because of an Increase in the varlance of husbands' wages, which actually declined slightly, but because of an increase in the variance of husbands' weeks worked. In addition, the rising covariance of Australian husbands' wages and weeks worked suggests that employment declined relatively more for low-wage workers, a finding that is consistent with the varlous factors Identified above as potentially leading to increased earnings inequality. 29

${ }^{29}$ One might speculate that these effects for Australla, which are based on 
In the United States and Canada, however, the Increased Inequality of husbands' earnings is assoclated with increases in both the varlance of husbands' wages and the varlance of their hours, as one would expect to be the case in relatively decentralized and unregulated labor markets. The fact that the dispersion of wages appears to have Increased more in the UnIted States than In Canada is consistent with a stronger union presence in Canada, but also with the fact that education-earnings differentials for men Increased in the United States, but not In Canada. 30 This latter difference appears to reflect a sharp rise in the supply of more educated men in Canada during the 1980s relative to the United States (see Freeman and Needels 1993).

After the 'Increase in husbands' earnings Inequality, the increasing correlation of husbands' and wives' earnings is the next most important correlate of increased income inequality among marrled couple families in the United states and Canada. We also find evidence that this correlation Increased in Sweden and the United KIngdom, but not in Australla, France, and the Netherlands. Our analyses show that the Increased interspousal correlation of earnings in Canada and the United States is associated with Increased interspousal correlations of wages, hours, and employment probabllities. Given the Increases that occurred in women's labor market activity In the United States and Canada during the 1980s, one might reasonably expect these Increased Interspousal correlations to reflect some

samples of husbands who report that they usually work full-time, would be even more pronounced among samples of all male workers.

${ }^{30}$ Comparing the magnitude of the wage inequality increase in the United states and Canada may be misleading, because different measures of the wage are used in analyzing the two countrles. Blackburn and Bloom (1993), however, show that the earnings inequality Increase is larger in the United States than in Canada when weekly earnings for full-time workers. are analyzed in both countries. 
changes in the matching of spouses with respect to Important labor market characteristics, but we found very little evidence to support this view. Indeed, the data Indicate that the interspousal correlation or predicted wages changed in both the United States and Canada because of changes in the way the labor markets translate Individual characteristics into wage outcomes. For example, Increased education-wage differentials for both husbands and wives in the United States seem to be assoclated with an Increase in the interspousal predicted wage correlation.

In part because standard sets of regressors explain relatively small fractions of the total variation in wages and hours, the dominant factor assoclated with increases in the interspousal correlations of wages and hours are Increases in the correlations between spouses of their wage residuals and of their hours residuals. This result closely parallels the findings of Blackburn (1990) and Juhn, Murphy, and Plerce (1993), who note the 1mportance of changes in unobservable influences on wages to the rise in wage Inequality among United States men. Our results confirm the 1mportance of changes in unobservable influences in wage and hours equations to the increasing variance of husbands' and wives' wages and hours in the United States and Canada. They also suggest that these unobservable influences have become more highly correlated between spouses over time. If our findings about the stabllity of interspousal correlations of observed labor market characteristics extend to unobserved characteristics, our results suggest that changes have occurred in the welghts that translate unobserved characteristics into labor market outcomes, for example, that skill prices associated with certain labor market characteristics not controlled for in our analyses tended to increase in the 
1980s. ${ }^{31}$ However, this conclusion is highly speculative and deserves further analysis using data that will permit a richer specification of spouses' labor market characteristics. Additional analysis of income and earnings data for other countries and time perlods $1 \mathrm{~s}$ also needed before more definitive conclusions may be reached about the ways in which labor market institutions help condition an economy's wage and employment responses to important macroeconomic shifts.

31 Juhn, Murphy, and Plerce (1993) use similar loglc to interpret increases in the residual variance of wage equations for U.S. men in the 1980s. These authors conclude that the widening of education-wage differentials is largely a result of increased prices for unobservable skills. 
Baumol, Will lam, Sue Anne Batey Blackman, and Edward Wolff. 1985. "Unbalanced Growth Revisited: Asymptotic Stagnancy and New Evidence." American Economic Review. 75(4): 806-17.

Bhagwat1, Jagdish, and Vivek Dehej1a. 1993. "Freer Trade and Wages of the Unskilled: Is Marx Striking Again?" Unpublished manuscript, Columbia University.

Blackburn, Mckinley. 1990. What Can Explain the Increase in Earnings Inequality Among Males?" Industrial Relations. 29(3): 441-56.

Blackburn, McKinley, and David Bloom. 1987. "Earnings and Income Inequallty In the United States." Population and Development Review. 13(4): 575-609.

Blackburn, McKinley, and David Bloow. 1993. "The Distribution of Famlly Income: Measuring and Explaining Changes in the 1980s for Canada and the United States." In David Card and Richard Freeman, eds., Small Differences that Matter: Labor Markets and Income Maintenance in Canada and the United States. Chicago: University of Chicago Press, 233-66.

Blackburn, Mckinley, David Bloom, and Rlchard Freeman. 1990. "The Declining Economic Position of Less Skilled American Men." In Gary Burtless, ed., A Future of Lousy Jobs? The Changing Structure of U.S. Wages. Washington, D.C.: The Brookings Institution, 31-67.

Bound, John, and George Johnson. 1992. "Changes in the Structure of Wages During the 1980s: An Evaluation of Alternative Hypotheses." American Economic Review. 82(3): 371-92.

Bourguignon, Franco1s. 1979. "Decomposable Income Inequality Measures." Econometrica. 47(4): 901-20.

Burtless, Gary. 1990. "Earnings Inequality over the Business and Demographic Cycles." In Gary Burtless, ed., A Future of Lousy Jobs? The Changing structure of U.S. Wages. Washington, D.C.: The Brookings Institution, 77-116.

Cancian, Mar1a, Sheldon Danziger, and Peter Gottschalk. 1993. "Working Wives and Family Income Inequality among Marrled Couples." In Sheldon Danziger and Peter Gottschalk, eds., Uneven Tides: Rising Inequality in America. New York: Russell Sage Foundation, 195-222.

Card, David, and Alan Krueger. 1992. "Does School Quality Matter? Returns to Education and the Characteristics of Public Schools in the United States." Journal of Political Economy. 100(1): 1-40.

Findlay, Ronald. 1993. Wage Dispersion, International Trade and the Service Sector." In Gote Hansson, ed., Trade, Growth and Development: The Role of Polltics and Institutions. London: Routledge. 
Freeman, Richard, and Karen Needels. 1993. "Sk1ll Differentials in Canada in an Era of Rising Labor Market Inequality." In David Card and Richard Freeman, eds., Sme11 Differences that Matter: Labor Markets and Income Maintenance in Canada and the United States. Ch1cago: University of Ch1cago Press, 45-68.

Gronau, Reuben. 1982. "Inequality of Famlly Income: Do Wives' Earnings Matter?" Population and Development Review. 8(Supplement): 119-36.

Heckman, James. 1979. "Sample Selection Blas as a Specification Error." Econometrica. 47: 153-61.

Juhn, Ch1nhul, Kevin Murphy, and Brooks P1erce. 1993. "Wage Inequality and the Rise in Returns to Sk1ll." Journal of Political Economy. 101(3): 410-42.

Karoly, Lynn. 1993. "The Trend in Inequality Among Fam1lies, Individuals, and Workers in the United States: A Twenty-F1ve Year Perspective." In Sheldon Danziger and Peter Gottschalk, eds., Uneven Tides: Rising Inequality in America. New York: Russell Sage Foundation, 195-222.

Katz, Lawrence, Gary Loveman, and David Blanchflower. 1993. "A Comparison of Changes in the Structure of Wages in Four OECD Countries." NBER Working Paper No. 4297. Cambridge, Mass.: NBER.

Katz, Lawrence, and Ana Revenga. 1989. "Changes in the Structure of Wages: The United States vs Japan." Journal of the Japanese and International Economies. 3: 522-53.

Krueger, Alan B. "How Computers Have Changed the Wage Structure: Evidence from Microdata, 1984-89." Quarterly Journal of Economics, 108(1): 33-60.

Lehrer, Evelyn, and Marc Nerlove. 1984. "A Life-Cycle Analysis of Family Income D1stribution." Economic Inqulry. 22: $360-74$.

Leontief, Wassily. 1982. "Technological Advance, Economlc Growth, and the Distribution of Income." Population and Development Review 9 (3): 403-10.

Mincer, Jacob. 1993 "Human Cap1tal, Technology, and the Wage Structure: What Do Time Ser1es Show?" In Studies in Human Capital: Collected Essays of Jacob Mincer. Brookfleld, Vermont: Edward Elgar, 366-405.

Moghadam, Reza. 1990. "Wage Determination: An Assessment of Returns to Education, Occupation, Region and Industry in Great Britain." Discussion Paper No. 8, London: Centre for Econom 1c Performance.

Murphy, Kevin, and Finis Welch. 1991. "The Role of International Trade in Wage Differentials. In Marvin Kosters, ed. Workers and their Wages. Washington, D.C.: AEI Press.

Schirm, Allen. 1988. "Mar1tal Sorting, Wives' Labor Supply, and Fam1ly Income Inequal1ty." Unpublished manuscript. 
Smeeding, Timothy M., Michael O'Higgins, and Lee Rainwater, Eds. 1990.

Poverty, Inequality and Income Distribution in Comparative Perspective: The Luxembourg Income Study (LIS). Washington, D.C.: The Urban Institute

Press.

Smith, James P. 1979. "The Distribution of Famlly Earnings." Journal of Polltical Economy. 87(5,pt. 2): s163-92. 
Table 1

Inequality of Total Income Among Married-Couple Famllies, Selected Years ${ }^{a}$

\begin{tabular}{|c|c|c|c|}
\hline \multirow[b]{2}{*}{ Country and Year } & \multicolumn{2}{|c|}{ Inequal1ty Measure $e^{b}$} & \\
\hline & $M L D$ & $E N T$ & $c v^{2}$ \\
\hline \multicolumn{4}{|l|}{ Untted States } \\
\hline $\begin{array}{l}1979 \\
1987\end{array}$ & $\begin{array}{l}.198 \\
.224\end{array}$ & $\begin{array}{l}.145 \\
.167\end{array}$ & $\begin{array}{l}.304 \\
.349\end{array}$ \\
\hline \multicolumn{4}{|l|}{ Canada } \\
\hline $\begin{array}{l}1979 \\
1987\end{array}$ & $\begin{array}{l}.167 \\
.163\end{array}$ & $\begin{array}{l}.125 \\
.135\end{array}$ & $\begin{array}{l}.256 \\
.285\end{array}$ \\
\hline $\begin{array}{r}\text { Australiac }^{c} \\
1981 / 82 \\
1985 / 86\end{array}$ & $\begin{array}{l}.251 \\
.264\end{array}$ & $\begin{array}{l}.158 \\
.164\end{array}$ & $\begin{array}{l}.342(.459) \\
.358(.483)\end{array}$ \\
\hline
\end{tabular}

${ }^{8}$ Total income includes earned and unearned cash Income, excluding capital gains and one-time; lump-sum payments.

$b_{\text {MID }}$ is the mean logarithmic deviation, ENT is The $11^{\prime}$ s entropy measure, and $C V^{2}$ is the squared coefficlent of varlation. For Incomes $y_{1}, 1-1, \ldots$, these measures are calculated using the following formulas:

$$
\begin{aligned}
& \text { MLD }=\frac{1 n}{n} \sum_{1-1} \log \left(\bar{y} / y_{i}\right) ; \\
& \text { ENT }=\frac{1}{n \bar{y}} \sum_{1-1}^{n} y_{i} \log \left(y_{i} / \bar{y}\right) ; \text { and } \\
& C V^{2}=\frac{n \sum_{1}\left(y_{1}-\bar{y}\right)}{n \bar{y}^{2}}
\end{aligned}
$$

where $\bar{y}-\bar{\Sigma}_{1} y_{1} / n$. All three measures are Increasing functions of the degree of inequality.

The Australian statistics are for Income excluding Interest and dividends. The numbers in parentheses are calculated using the distribution of interest and dividend income from 1985/86 in the calculations for both years. 
Table 2

Components of the Squared Coefficient of Variation of Total Income for Married Couple Families in the United States, 1979 and 1987

\begin{tabular}{|c|c|c|c|c|c|}
\hline \multirow[b]{2}{*}{ Item } & \multicolumn{5}{|c|}{ Income Source } \\
\hline & $\begin{array}{l}\text { Husbands' } \\
\text { Earnings }\end{array}$ & $\begin{array}{l}\text { Wives' } \\
\text { Earnings }\end{array}$ & $\begin{array}{c}\text { Other } \\
\text { Earnings }\end{array}$ & $\begin{array}{l}\text { Interest } \\
\text { and } \\
\text { Dividends }\end{array}$ & $\begin{array}{l}\text { Other } \\
\text { Income }\end{array}$ \\
\hline$\frac{1979}{\mathrm{Share}^{2}}$ & $\begin{array}{l}.68 \\
.42\end{array}$ & $\begin{array}{r}.17 \\
1.70\end{array}$ & $\begin{array}{r}.06 \\
7.49\end{array}$ & $\begin{array}{r}.04 \\
13.93\end{array}$ & $\begin{array}{r}.05 \\
6.64\end{array}$ \\
\hline $\begin{array}{l}\text { Correlation with: } \\
\text { Husbands ' earnings } \\
\text { Wives' earnings } \\
\text { Other earnings } \\
\text { Interest and dividends } \\
\text { Other income }\end{array}$ & $\begin{array}{r}.- \\
.01 \\
.04 \\
.15 \\
. .27\end{array}$ & $\begin{array}{l}(.10)^{a} \\
-- \\
.00 \\
-.00 \\
-.05\end{array}$ & $\begin{array}{l}.04 \\
.04\end{array}$ & .06 & \\
\hline$\frac{\frac{1987}{\text { Share }}}{C V^{2}}$ & $\begin{array}{l}.63 \\
.48\end{array}$ & $\begin{array}{r}.22 \\
1.39\end{array}$ & $\begin{array}{r}.05 \\
9.42\end{array}$ & $\begin{array}{r}.05 \\
11.46\end{array}$ & $\begin{array}{r}.05 \\
6.57\end{array}$ \\
\hline $\begin{array}{l}\text { Correlation with: } \\
\text { Husbands' earnings } \\
\text { Wives' earnings } \\
\text { Other earnings } \\
\text { Interest and dividends } \\
\text { Other income }\end{array}$ & $\begin{array}{r}. . \\
.11 \\
.04 \\
.15 \\
-.25\end{array}$ & $\begin{array}{c}(.18)^{a} \\
-. \\
.01 \\
.02 \\
-.09\end{array}$ & $\begin{array}{l}.03 \\
.05\end{array}$ & .09 & \\
\hline
\end{tabular}

"This statistic is the correlation coefficient between husbands" and wives' earnings among families with positive amounts for both husbands' and wives" earnings. 
Decomposition of Changes in $\mathrm{CV}^{2}$ in the United states, $1979-87$

\begin{tabular}{lcc} 
Actual Change $=.045$ & & \\
\hline $\begin{array}{l}\text { Percent of Change } \\
\text { Associated with Changes in: }\end{array}$ & $\begin{array}{r}1979 \text { Base } \\
\text { Parameters }\end{array}$ & $\begin{array}{r}1987 \text { Bese } \\
\text { Parameters }\end{array}$ \\
\hline $\mathrm{CV}^{2}$ for husbands & 628 & 58 \\
$\mathrm{CV}^{2}$ for wives & -20 & -38 \\
p for husband and wife & 44 & 51 \\
$\begin{array}{l}\text { Income shares } \\
\text { Share shlft from } \\
\text { husband to wife }\end{array}$ & 31 & 7 \\
\end{tabular}

an calculating this statistic, the share of income from husbands' earnings was reduced by the amount of the increase in the share of income from wives' earnings, while the other income source shares were left unchanged. This comention preserves the constraint that all income shares sum to unity. 
Table 4

Components of the Squared Coefficlent of Varlation among Married Couple Familles, Canada and Australla, Selected Years

\begin{tabular}{|c|c|c|c|c|c|}
\hline \multirow[b]{2}{*}{ Item } & \multicolumn{5}{|c|}{ Income Source } \\
\hline & $\begin{array}{l}\text { Kusbands' } \\
\text { Earnings }\end{array}$ & $\begin{array}{c}\text { Wives' } \\
\text { Earnings }\end{array}$ & $\begin{array}{c}\text { Other } \\
\text { Earnings }\end{array}$ & $\begin{array}{l}\text { Interest } \\
\quad \text { and } \\
\text { Dividends }\end{array}$ & $\begin{array}{l}\text { Other } \\
\text { Income }\end{array}$ \\
\hline \multicolumn{6}{|c|}{ Canada } \\
\hline$\frac{1979}{\operatorname{Share}^{2}}$ & $\begin{array}{l}.66 \\
.34\end{array}$ & $\begin{array}{r}.17 \\
1.76\end{array}$ & 6.08 & $\begin{array}{r}.04 \\
10.85\end{array}$ & $\begin{array}{l}.05 \\
2.98\end{array}$ \\
\hline $\begin{array}{l}\text { Correlation with: } \\
\text { Husbands' earnings } \\
\text { Wives' earnings } \\
\text { Other earnings } \\
\text { Interest and dividends } \\
\text { Other Income }\end{array}$ & $\begin{array}{r}. . \\
.02 \\
-.00 \\
.04 \\
-.30\end{array}$ & $\begin{array}{r}(.06) \\
- \\
-.01 \\
.03 \\
-.09\end{array}$ & $\begin{array}{l}.06 \\
.07\end{array}$ & .02 & \\
\hline$\frac{1987}{\text { Share }^{2}}$ & $\begin{array}{l}.59 \\
.44\end{array}$ & $\begin{array}{r}.22 \\
1.31\end{array}$ & $\begin{array}{r}.07 \\
6.84\end{array}$ & $\begin{array}{r}.04 \\
11.55\end{array}$ & $\begin{array}{l}.08 \\
2.85\end{array}$ \\
\hline $\begin{array}{l}\text { Correlation with: } \\
\text { Husbands' oarnings } \\
\text { Wives' earnings } \\
\text { Other earnings } \\
\text { Interest and dividends } \\
\text { Other Income }\end{array}$ & $\begin{array}{r}.- \\
.16 \\
.01 \\
.07 \\
-.33\end{array}$ & $\begin{array}{c}(.21) \\
-. \\
-.02 \\
.04 \\
-.17\end{array}$ & $\begin{array}{l}.06 \\
.04\end{array}$ & .06 & \\
\hline \multicolumn{6}{|c|}{ Australla } \\
\hline$\frac{1981 / 82}{\operatorname{Share}^{2}}$ & $\begin{array}{l}.61 \\
.44\end{array}$ & $\begin{array}{r}.19 \\
1.78\end{array}$ & $\begin{array}{r}.08 \\
7.86\end{array}$ & $\begin{array}{r}.07 \\
22.93\end{array}$ & $\begin{array}{l}.05 \\
3.98\end{array}$ \\
\hline $\begin{array}{l}\text { Correlation with: } \\
\text { Husbands' earnings } \\
\text { WIves' earnings } \\
\text { Other earnings } \\
\text { Interest and dividends } \\
\text { Other Income }\end{array}$ & $\begin{array}{r}. . \\
.17 \\
.01 \\
.16 \\
-.27\end{array}$ & $\begin{array}{c}(.21) \\
-. \\
.01 \\
.06 \\
-.17\end{array}$ & $\begin{array}{l}.05 \\
.01\end{array}$ & -.02 & \\
\hline
\end{tabular}


Table 4 (continued)

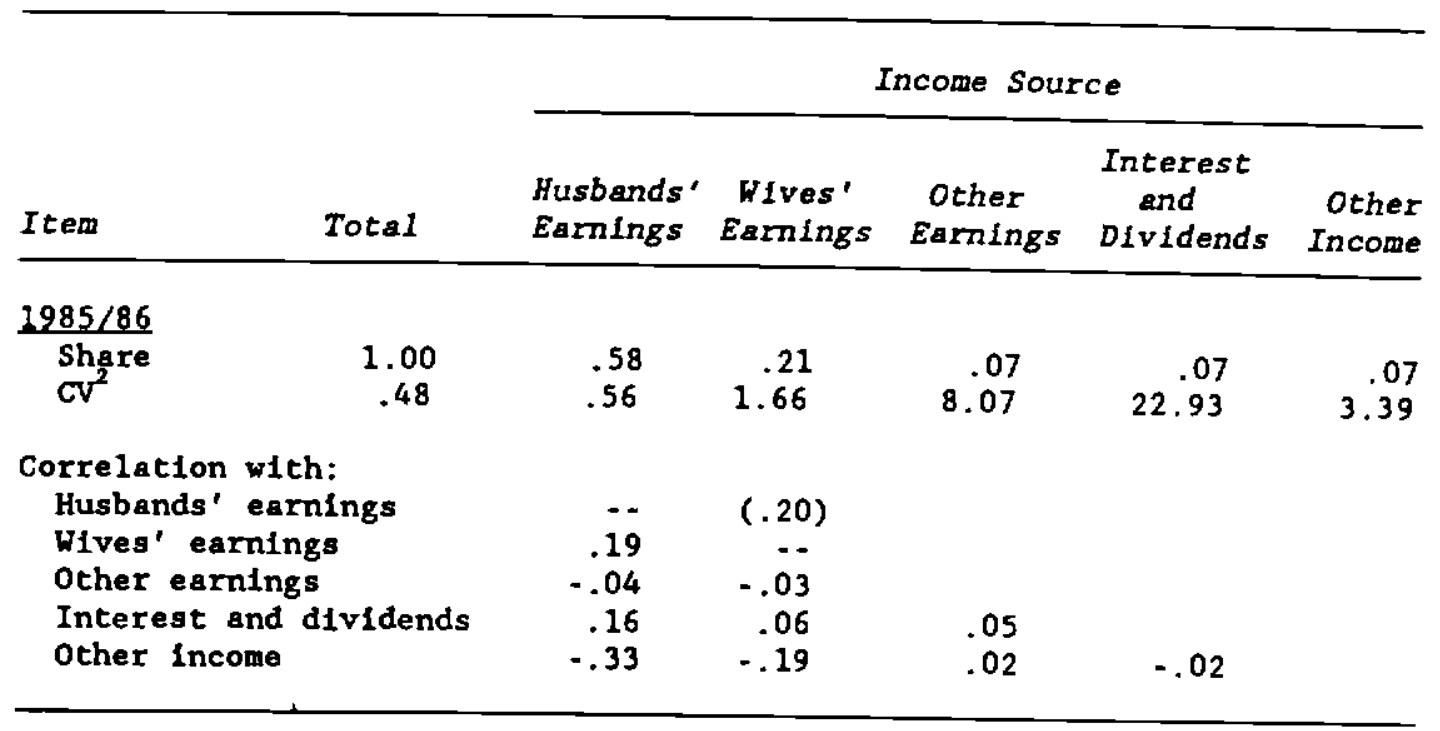

${ }^{a}$ For reasons noted in the text, the 1981/82 entries for the $c v^{2}$ and correlations involving interest and dividend income are taken from the calculations using the 1985/86 data. 
Table 5

Decomposition of Changes in $\mathrm{Cv}^{2}$, Canada and Australla, Selected Years

Canada (Actual Change -.029 )

\begin{tabular}{lcc}
\hline $\begin{array}{l}\text { Percent of Change } \\
\text { Assoclated with Changes in: }\end{array}$ & $\begin{array}{c}1979 \text { Base } \\
\text { Parameters }\end{array}$ & $\begin{array}{c}1987 \text { Base } \\
\text { Parameters }\end{array}$ \\
\hline $\mathrm{CV}^{2}$ for husbands & 145 & 124 \\
$\mathrm{VV}^{2}$ for wives & -45 & -86 \\
for husband and wife & 83 & 97 \\
Income shares & -17 & -83 \\
$\begin{array}{c}\text { Share shift fron } \\
\text { husband to wife }\end{array}$ & 48 & 14 \\
\hline
\end{tabular}

Australla (Actual Change - .024)

\begin{tabular}{lcc}
\hline Percent of Change & $\begin{array}{c}1981 / 82 \text { Base } \\
\text { Parameters }\end{array}$ & $\begin{array}{c}1985 / 86 \text { Base } \\
\text { Parameters }\end{array}$ \\
Assoclated wlth Changes in: & 179 & 159 \\
\hline$V^{2}$ for husbands & -17 & -24 \\
CV for wives & 14 & 17 \\
p for husband and wife & -55 & -79 \\
Income shares & 21 & 7 \\
Share shift from & & \\
husband to wife & & \\
\hline
\end{tabular}


Table 6

Selected Components of the Inequality Decomposition, Varlous Countries and Time Perlods

\begin{tabular}{|c|c|c|c|c|c|}
\hline \multirow[b]{3}{*}{ Country/Year } & \multicolumn{2}{|c|}{$c V^{2}$ for } & \multirow{3}{*}{$\begin{array}{l}\text { Hives' } \\
\text { Eamings' } \\
\text { Share }\end{array}$} & \multirow{2}{*}{\multicolumn{2}{|c|}{$\begin{array}{l}\text { Correlation of } \\
\text { Husbands' and WIves' } \\
\text { Earnings }\end{array}$}} \\
\hline & Tatal & Bushends' & & & \\
\hline & Income & EamIngs & & A11 & Both Earners \\
\hline $\begin{array}{l}\text { United States } \\
\quad 1991\end{array}$ & .36 & .53 & .25 & .11 & .19 \\
\hline $\begin{array}{r}\text { France } \\
1979 \\
1984\end{array}$ & $\begin{array}{l}.70 \\
.73\end{array}$ & $\begin{array}{l}1.09 \\
1.33\end{array}$ & $\begin{array}{l}.16 \\
.18\end{array}$ & $\begin{array}{l}.13 \\
.16\end{array}$ & $\begin{array}{l}.29 \\
.29\end{array}$ \\
\hline $\begin{array}{l}\text { Netherlands } \\
1983 \\
1987\end{array}$ & $\begin{array}{l}.38 \\
.32\end{array}$ & $\begin{array}{l}.70 \\
.60\end{array}$ & $\begin{array}{l}.10 \\
.12\end{array}$ & $\begin{array}{l}.11 \\
.06\end{array}$ & $\begin{array}{l}.14 \\
.14\end{array}$ \\
\hline $\begin{array}{r}\text { Sweden } \\
1981 \\
1987\end{array}$ & $\begin{array}{l}.21 \\
.21\end{array}$ & $\begin{array}{l}.26 \\
.28\end{array}$ & $\begin{array}{l}.26 \\
.28\end{array}$ & $\begin{array}{l}.21 \\
.25\end{array}$ & $\begin{array}{l}.15 \\
.21\end{array}$ \\
\hline $\begin{array}{l}\text { United KIngdor } \\
1979 \\
1986\end{array}$ & $\begin{array}{l}.25 \\
.39\end{array}$ & $\begin{array}{l}.49 \\
.93\end{array}$ & $\begin{array}{l}.15 \\
.16\end{array}$ & $\begin{array}{l}.09 \\
.18\end{array}$ & $\begin{array}{l}.13 \\
.20\end{array}$ \\
\hline
\end{tabular}


Table 7

Varlances and Correlations of U.S. Husbands' and Wives' Earnings and Other Characteristics, 1979 and 1987

A: Components of varlance of $\log$ earnings ${ }^{8}$

\begin{tabular}{|c|c|c|c|c|c|c|}
\hline \multirow[b]{2}{*}{ Year } & \multicolumn{3}{|c|}{ Husbands } & \multicolumn{3}{|c|}{ Hives } \\
\hline & $\begin{array}{c}\text { Log } \\
\text { Hages }\end{array}$ & $\begin{array}{c}\text { Log } \\
\text { Hours }\end{array}$ & Cov. & $\underset{\text { Lages }}{\text { Lages }}$ & $\log _{\text {Hours }}$ & Cov. \\
\hline $\begin{array}{l}1979 \\
1987\end{array}$ & $\begin{array}{l}.326 \\
.371\end{array}$ & $\begin{array}{l}.176 \\
.221\end{array}$ & $\begin{array}{l}.012 \\
.013\end{array}$ & $\begin{array}{l}.337 \\
.377\end{array}$ & $\begin{array}{r}1.061 \\
.855\end{array}$ & $\begin{array}{l}.046 \\
.052\end{array}$ \\
\hline
\end{tabular}

B: Correlation between husbands' and wives' characterlstics

\begin{tabular}{llllllll}
\hline Year & Education & Age & $P$ & $\log (E)$ & $\log (W)$ & $\log (H)$ \\
\hline 1979 & .65 & .93 & .10 & .05 & .20 & .02 \\
1987 & .65 & .91 & .15 & .11 & .28 & .02 \\
\hline
\end{tabular}

Notes:

$\begin{array}{lll}\text { Cov. } & \text { - Covarlance between the } \log \text { of wages and the } 10 \mathrm{~g} \text { of hours. } \\ \text { P } & \text { - Employment Indicator (equal to one if Individual worked }\end{array}$

$\log (E) \quad$ during survey year, zero otherwise).

$\log (w)$ - Logarithm of hourly income, defined as annual earnings divided by annual hours worked, for Individuals with positive hours (Individuals with wages below $\$ 1$ in 1987 dollars were

$\log (\mathrm{H})$ excluded).

Logarlthm of annual hours worked, for Individuals with

Wage varlances and wage-hours covarlances are calculated using that part of the sample that gatiafles our exclusion restrlctions for wages, which is smaller than the corresponding samples of Individuals with positive hours. Education, age, and employment correlations are calculated using the complete
sample. 
Table 8

Interspousal Correlations of Predicted Values and Residuals, Unlted States, 1979 and 1987

\begin{tabular}{|c|c|c|c|c|c|c|}
\hline \multirow{2}{*}{$\begin{array}{l}\text { Correlation } \\
\text { Between }\end{array}$} & \multicolumn{2}{|c|}{ Employment } & \multicolumn{2}{|c|}{ Weeks } & \multicolumn{2}{|c|}{ Wages } \\
\hline & 1979 & 1987 & 1979 & 1987 & 1979 & 1987 \\
\hline Predlcted values $^{a}$ & .80 & .84 & .10 & .24 & .57 & .62 \\
\hline Reglduals & -.04 & -.04 & .02 & .01 & .14 & .17 \\
\hline $\begin{array}{l}\text { Predlcted values } \\
\text { (with } 1979 \\
\text { coefflclents) }\end{array}$ & .80 & .82 & .10 & .18 & .57 & .58 \\
\hline
\end{tabular}

${ }^{a}$ Predicted value correlations are calculated using the sample of all marrled couples. The residual correlations for the hours and wage equations can only be calculated for dual earner marrled couples. 
Table 9

Variances and Correlations of Husbands' and WIves' Earnings and Other Characteristics, Canada and Australla

A: Components of variance of $10 \mathrm{~g}$ earnings

\begin{tabular}{|c|c|c|c|c|c|c|}
\hline \multirow[b]{2}{*}{ Year } & \multicolumn{3}{|c|}{ Husbands } & \multicolumn{3}{|c|}{ Wives } \\
\hline & $\begin{array}{c}\log \\
\text { Wages }\end{array}$ & $\begin{array}{c}\text { Log } \\
\text { Hours }\end{array}$ & Cov. & $\begin{array}{c}\log \\
\text { Wages }\end{array}$ & $\underset{\text { Hours }}{\log }$ & Cov. \\
\hline \multicolumn{7}{|l|}{ Canada } \\
\hline $\begin{array}{l}1979 \\
1987\end{array}$ & $\begin{array}{l}.319 \\
.338\end{array}$ & $\begin{array}{l}.096 \\
.166\end{array}$ & $\begin{array}{r}-.003 \\
.017\end{array}$ & $\begin{array}{l}.339 \\
.380\end{array}$ & $\begin{array}{l}.346 \\
.381\end{array}$ & $\begin{array}{r}. .004 \\
.033\end{array}$ \\
\hline $\begin{array}{c}\text { Austra11a } \\
1981 / 2 \\
1985 / 6\end{array}$ & $\begin{array}{l}.254 \\
.246\end{array}$ & $\begin{array}{l}.080 \\
.094\end{array}$ & $\begin{array}{l}.005 \\
.009\end{array}$ & $\begin{array}{l}.227 \\
.235\end{array}$ & $\begin{array}{l}.469 \\
.375\end{array}$ & $\begin{array}{l}.017 \\
.029\end{array}$ \\
\hline
\end{tabular}

B: Correlation between husbands' and wives' characteristics

\begin{tabular}{lcccccc}
\hline Year & Education & Age & $P$ & $\log (E)$ & $\log (w)$ & $\log (H)$ \\
\hline $\begin{array}{c}\text { Canada } \\
1979\end{array}$ & .63 & .93 & .12 & .04 & .11 & .10 \\
1987 & .62 & .93 & .20 & .12 & .22 & .15 \\
$\begin{array}{llll}\text { Austra11a } \\
1981 / 2 \\
1985 / 6\end{array}$ & .41 & .92 & .24 & .13 & .35 & .15 \\
& .44 & .91 & .31 & .16 & .31 & .15 \\
\hline
\end{tabular}

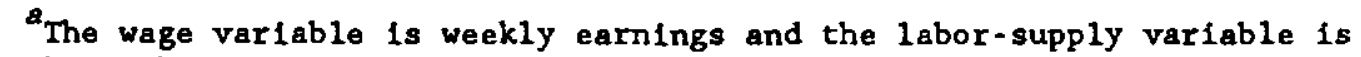
weeks worked over the year. The samples are restricted to full-time workers (more than 30 hours per week). See notes to table 7 for further detalls.

$b_{A}$ continuous years of education variable was constructed by using the avallable education codes to impute years of education. 
Table 10

Interspousal Correlations of Predicted Values and Residuals, Canada, 1979 and 1987

\begin{tabular}{|c|c|c|c|c|c|c|}
\hline \multirow{2}{*}{$\begin{array}{l}\text { Correlation } \\
\text { Between }\end{array}$} & \multicolumn{2}{|c|}{ Employment } & \multicolumn{2}{|c|}{ Weeks } & \multicolumn{2}{|c|}{ Hages } \\
\hline & 1979 & 1987 & 1979 & 1987 & 1979 & 1987 \\
\hline Predicted values & .74 & .86 & .65 & .84 & .62 & .58 \\
\hline Residuala & -.02 & -.03 & .12 & .16 & .05 & .12 \\
\hline $\begin{array}{l}\text { Predicted values } \\
\text { (with } 1979 \\
\text { coefflcients) }\end{array}$ & .74 & .74 & .65 & .65 & .62 & .63 \\
\hline
\end{tabular}


Appendix A

Selected Feetures of the Different Dato Sets Analyzed

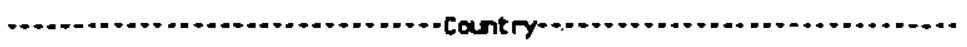

United

Itsen

States

Canoda

Australio

1. Nom of

deta set(s)

moreh Current

Population

survey of Conouner

surver (CPS)

FInence (SCF)

Income and housing

survey;

Income of stribution

survey

2. Yeore

1900

1960

1980

191/82;

1988

1985/86

3. Sample unit

Household, with

Sance U.S.

Same as U.S.

Information on all

individule residing

in housethold.

60,000

40,000

15,000 ;

Approximate

number of

imple units

included in

esch surver

5. Dofinition

of the farlly

Two or nore

individuls related

Seme U.S.

Serne es U.S.

by blood or morriage

and IIving in the

seme hasehold; plus

indivlduals livina

elone in hasentolds

or $w$ th other

individuals to thom

they ora not related.

This deflnition

corresponda clasely

to the notion of in

"econoale failly." 
6. Incone

cover age

7. Reference period for

income date

8. Inpurted dete

Misalny date are inputed based on

the incomes of

income-reporting

respondents with

like charecterintica. pre tax.
Stm U.S., (though some information on

direct tex payments

is ovallable).
Sane U.S.

siallar to U.S.
Seme as U.S.

\author{
July 1981 to \\ une 1982; \\ July 19a5 to \\ dune 1986.
}

sinilar to U.S.
9. Top-cosing of income date
All Income nources in the 1960 cos ore top-coded it 50,000 (1970) us dollors. Al though the nominat top-cods we 99,999 (19en us dollers in the 1906 cos, we applied the 1980 topcode (in real terns) to -11 of the 1988 cos income date me analyzed.
All Income cources in the two SCF date sets are topcoded, ot velues that very ecroses provinces and over tín. A constent real top-code (equel to the cenedien equivelent of 50,000 (1979) U.S. dol lars) weseplied to all of the scF incone dato we analyzed.
Hich incomes ore wakked by overnoing then wors other highincome people in the suse data cluster. 
Iten

10. Calculation of mpe

varíable

19. Under-

reporting

of incom
United

staty

Anuel earníngs

divided by ewnul

hours worked, with

Individuals havine

- calculated wage

below 51 per howr

(in 1907 U.S.

dollare) excluded

from the sumple.
Cenodin

Amul eaminos

divided by meeks

worked for tull.

tien workers (i.e..,

30 or more hours per

week), excluding

from the smople

individuals with

weekly unee below

240 (1987 U.S.

dollara).

Similer to U.S., except for ment

incame, wich in

reported eomenthat

more completely

then in the U.S.
Australin

Amul earnims:

divided by weeks

worked for

Individual s tho are

prínorily full-tín

workers (1.e., 30

or more hours per

neek), excluding

fron the sumple

Individene with

weekly wopes below

240 (1967 U.S.

dollers).

Wo Information. over tlove, and mord

Income and asset

Incone than for earned

Incorve. 
Append1x B

Effect of Changes in Wage Equation Parameters on the Correlation Between Wages across Individuals

In this appendix, we consider how changes in the parameters of two wage (or hours) functions can affect the correlation of the two function outcomes.

To begin with, we assume that only one varlable (for example, years of schooling) enters the two wage functions, that 1s,

$$
\begin{aligned}
& w_{1}-\beta_{1} x_{1} \\
& w_{2}-\beta_{2} x_{2}
\end{aligned}
$$

where the error terms are omitted so as to focus on the correlation in predicted values from the usual vage equations. Then the correlation between $w_{1}$ and $w_{2}$ is:

$$
\rho=\frac{\beta_{1} \beta_{2} c\left(x_{1}, x_{2}\right)}{\beta_{1} \sigma_{x_{1}} \beta_{2} \sigma_{x_{2}}}-\frac{c\left(x_{1}, x_{2}\right)}{\sigma_{x_{1}} \sigma_{x_{2}}},
$$

where $c\left(x_{1}, x_{2}\right)$ is the covarlance between $x_{1}$ and $x_{2}, \sigma_{y}$ is short-hand for the standard deviation of a variable $y$, and $\rho$ is the correlation coefficient between $w_{1}$ and $w_{2}$. As $\rho$ simplifies to the correlation coefficlent between $x_{1}$ and $x_{2}$, changes in $\beta_{1}$ and $\beta_{2}$ w111 not affect $\rho$, but changes in the correlation between $x_{1}$ and $x_{2}$ w111.

Th1s result changes, however, when more than one varlable determines wages. For Instance, let the varlables $z_{1}$ and $z_{2}$ enter the wage equations, that is:

$$
\begin{aligned}
& w_{1}-\beta_{1} x_{1}+\gamma_{1} z_{1} \\
& w_{2}-\beta_{2} x_{2}+\gamma_{2} z_{2}
\end{aligned}
$$


Now, the correlation between $w_{1}$ and $w_{2}$ 1s:

$$
\rho=\frac{\beta_{1} \beta_{2} C\left(x_{1}, x_{2}\right)+\beta_{1} \gamma_{2} C\left(x_{1}, z_{2}\right)+\gamma_{1} \beta_{2} C\left(z_{1}, x_{2}\right)+\gamma_{1} \gamma_{2} C\left(z_{1}, z_{2}\right)}{\left(\beta_{1}^{2} \sigma_{x}^{2}+2 \beta_{1} \gamma_{1} C\left(x_{1}, z_{1}\right)+\gamma_{1}^{2} \sigma_{z_{1}}^{2}\right)^{1 / 2}\left(\beta_{2}^{2} x_{2}^{2}+2 \beta_{2} \gamma_{2} C\left(x_{2}, z_{2}\right)+\gamma_{2}^{2}{ }_{2}^{2}\right)^{1 / 2}}
$$

for whlch,

$$
\frac{\partial \rho}{\partial \beta_{1}}-\frac{\rho}{\beta_{1}}\left(\frac{\beta_{1} \beta_{2} C\left(x_{1}, x_{2}\right)+\beta_{1} \gamma_{2} C\left(x_{1}, z_{2}\right)}{C\left(w_{1}, w_{2}\right)}-\frac{\beta_{1}^{2} \sigma_{x_{1}}^{2}+\beta_{1} \gamma_{1} C\left(x_{1}, z_{1}\right)}{\sigma_{w_{1}}^{2}}\right)
$$

so that increases in $\beta_{1}$ can elther increase or decrease $\rho$, depending on the signs and sizes of the relevant parameters. In fact, the above formula leads to the following conclusion: if $\beta_{1}>0$, then $\partial_{\rho} / \partial \beta_{1}$ will be positive (negative) If the percentage of the covariance between $w_{1}$ and $w_{2}$ that is attributable to terms 1nvolving $x_{1}$ 1s greater than (less than) the percentage of the variance of $w_{1}$ that is attributable to terms involving $x_{1} \cdot 32$ (If $\beta_{1}<0$, then the opposite conclusion holds.) An immediate Implication is that, holding other variances and covarlances constant, an Increase in the covariance between $x_{1}$ and $x_{2}$ (and so the correlation between $x_{1}$ and $x_{2}$ ) will increase the 11kelihood that increases in $\beta_{1}$ (or $\beta_{2}$ ) will Increase $\rho$.

${ }^{32}$ The portion of the variance of $w_{1}$ attributable to $x_{1}$ is defined so that one-half of the covarlance terms lnvolving $x_{1}$ are said to be attributed to $x_{1}$, and the other half attributed to the other varlable involved in the covariance. 
Append1x Table C1

OIS Estimates of Labor Karket Equations, United States, 1979 and $1987^{\circ}$

\begin{tabular}{|c|c|c|c|c|c|c|}
\hline \multirow{2}{*}{$\begin{array}{l}\text { Independent } \\
\operatorname{Varlable} e^{b}\end{array}$} & \multicolumn{2}{|c|}{ Employment } & \multicolumn{2}{|c|}{ Hours } & \multicolumn{2}{|c|}{ Hages } \\
\hline & 1979 & 1987 & 1979 & 1987 & 1979 & 1987 \\
\hline
\end{tabular}

Husbands

Education spline:

Education $\leq 8$

$\begin{array}{llllll}.008 & .003 & .028 & .009 & .054 & .037 \\ (.002) & (.002) & (.004) & (.005) & (.004) & (.005)\end{array}$

Education $>8$

$\begin{array}{cccccc}.004 & .005 & .009 & .014 & .061 & .074 \\ (.001) & (.001) & (.001) & (.001) & (.001) & (.001)\end{array}$

Age

$\begin{array}{llll}.029 & .035 & .021 & .031\end{array}$

$.053 \quad .056$

$(.002) \quad(.002)$

$(.003)(.004)$

$(.003) \quad(.003)$

Age $^{2} / 100$

$-.037-.045$

$-.027$

$-.042$

$-.053 \quad-.055$

$(.002) \quad(.002)$

(.003) (.004)

$(.003) \quad(.003)$

$\mathrm{R}^{2}$

N

$\hat{\sigma}^{2}$

$\begin{array}{rrrrrr}.10 & .14 & .04 & .04 & .14 & .16 \\ 31746 & 26900 & 29032 & 24272 & 28792 & 24028 \\ .065 & .071 & .169 & .212 & .282 & .311\end{array}$

WLes

Education spline:

Education $\leq 8$

$$
\begin{array}{llllll}
-.004 & -.004 & -.021 & -.010 & -.015 & -.007 \\
(.004) & (.004) & (.014) & (.014) & (.007) & (.008)
\end{array}
$$

Education $>8$

$\begin{array}{llllll}.018 & .022 & .030 & .036 & .071 & .091 \\ (.001) & (.001) & (.004) & (.004) & (.002) & (.002)\end{array}$

Age

$$
\begin{array}{llllll}
.039 & .034 & .050 & .065 & .024 & .043 \\
(.002) & (.002) & (.008) & (.007) & (.003) & (.003)
\end{array}
$$

Age $^{2} / 100$

$$
\begin{array}{llllll}
-.057 & -.050 & -.062 & -.084 & -.026 & -.048 \\
(.003) & (.003) & (.009) & (.009) & (.004) & (.004)
\end{array}
$$

\begin{tabular}{lrrrrrr}
$\mathrm{R}^{2}$ & .29 & .31 & .04 & .04 & .10 & .15 \\
$\mathrm{~N}$ & 31746 & 26888 & 19699 & 18835 & 19117 & 18372 \\
$\hat{\sigma}^{2}$ & .165 & .143 & 1.020 & .820 & .305 & .320 \\
\hline
\end{tabular}




\section{Appendix Table $\mathrm{Cl}$ (continued)}

a The employment equations are linear probability models for working or not working over the income year. The hours equations use the logarithm of annual hours as the dependent variable, and are estimated using the sample of Individuals with positive hours worked. The wage equations use the logarithin of annual earnings divided by annual hours worked as the dependent varlable.

${ }^{b}$ All regressions include three region dummies and the number of nonearners in the famlly as Independent varlables. The employment and hours regressions also include the spouse's education and age varlables as Independent varlables. 
Append1x Tab1e $\mathrm{C2}$

OLS Estimates of Labor-Market Equations, Canada, 1979 and $1987^{a}$

\begin{tabular}{|c|c|c|c|c|c|c|}
\hline \multirow{2}{*}{$\begin{array}{l}\text { Independent } \\
\operatorname{Varlab} 1 e^{b}\end{array}$} & \multicolumn{2}{|c|}{ Employment } & \multicolumn{2}{|c|}{ Hours } & \multicolumn{2}{|c|}{ Wages } \\
\hline & 1979 & 1987 & 1979 & 1987 & 1979 & 1987 \\
\hline \multicolumn{7}{|l|}{ Husbands } \\
\hline High school & $\begin{array}{l}.014 \\
(.004)\end{array}$ & $\begin{array}{l}.019 \\
(.004)\end{array}$ & $\begin{array}{l}.071 \\
(.006)\end{array}$ & $\begin{array}{c}.108 \\
(.008)\end{array}$ & $\begin{array}{l}.149 \\
(.010)\end{array}$ & $\begin{array}{l}.136 \\
(.010)\end{array}$ \\
\hline Some college & $\begin{array}{l}.008 \\
(.005)\end{array}$ & $\begin{array}{l}.018 \\
(.005)\end{array}$ & $\begin{array}{l}.066 \\
(.007)\end{array}$ & $\begin{array}{l}.103 \\
(.009)\end{array}$ & $\begin{array}{l}.190 \\
(.012)\end{array}$ & $\begin{array}{l}.224 \\
(.011)\end{array}$ \\
\hline College graduate & $\begin{array}{l}.016 \\
(.006)\end{array}$ & $\begin{array}{l}.030 \\
(.006)\end{array}$ & $\begin{array}{c}.086 \\
(.009)\end{array}$ & $\begin{array}{c}.128 \\
(.011)\end{array}$ & $\begin{array}{c}.444 \\
(.013)\end{array}$ & $\begin{array}{l}.455 \\
(.013)\end{array}$ \\
\hline Age & $\begin{array}{c}.021 \\
(.002)\end{array}$ & $\begin{array}{c}.026 \\
(.002)\end{array}$ & $\begin{array}{l}.010 \\
(.003)\end{array}$ & $\begin{array}{c}.014 \\
(.004)\end{array}$ & $\begin{array}{l}.044 \\
(.003)\end{array}$ & $\begin{array}{l}.051 \\
(.003)\end{array}$ \\
\hline $\mathrm{Age}^{2} / 100$ & $\begin{array}{l}-.030 \\
(.002)\end{array}$ & $\begin{array}{l}-.037 \\
(.002)\end{array}$ & $\begin{array}{l}-.014 \\
(.003)\end{array}$ & $\begin{array}{l}-.018 \\
(.004)\end{array}$ & $\begin{array}{l}-.049 \\
(.004)\end{array}$ & $\begin{array}{l}-.054 \\
(.004)\end{array}$ \\
\hline $\begin{array}{l}R^{2} \\
N\end{array}$ & $\begin{array}{c}.13 \\
20053\end{array}$ & $\begin{array}{c}.20 \\
22248\end{array}$ & $\begin{array}{c}.07 \\
18341\end{array}$ & $\begin{array}{c}.09 \\
19858\end{array}$ & $\begin{array}{c}.09 \\
18186\end{array}$ & $\begin{array}{c}.10 \\
19688\end{array}$ \\
\hline$\hat{\sigma}_{c}^{2}$ & .041 & .053 & .090 & .152 & .290 & .304 \\
\hline \multicolumn{7}{|l|}{ Wives } \\
\hline High school & $\begin{array}{l}.057 \\
(.008)\end{array}$ & $\begin{array}{l}.069 \\
(.007)\end{array}$ & $\begin{array}{l}.129 \\
(.018)\end{array}$ & $\begin{array}{l}.146 \\
(.016)\end{array}$ & $\begin{array}{l}.144 \\
(.017)\end{array}$ & $\begin{array}{l}.181 \\
(.016)\end{array}$ \\
\hline Some college & $\begin{array}{l}.121 \\
(.010)\end{array}$ & $\begin{array}{l}.134 \\
(.008)\end{array}$ & $\begin{array}{l}.159 \\
(.021)\end{array}$ & $\begin{array}{l}.211 \\
(.018)\end{array}$ & $\begin{array}{l}.268 \\
(.019)\end{array}$ & $\begin{array}{l}.327 \\
(.016)\end{array}$ \\
\hline College graduate & $\begin{array}{l}.173 \\
(.015)\end{array}$ & $\begin{array}{c}.173 \\
(.011)\end{array}$ & $\begin{array}{l}.217 \\
(.030)\end{array}$ & $\begin{array}{l}.275 \\
(.024)\end{array}$ & $\begin{array}{l}.512 \\
(.025)\end{array}$ & $\begin{array}{l}.693 \\
(.020)\end{array}$ \\
\hline Age & $\begin{array}{l}.039 \\
(.003)\end{array}$ & $\begin{array}{l}.041 \\
(.003)\end{array}$ & $\begin{array}{l}.057 \\
(.008)\end{array}$ & $\begin{array}{l}.043 \\
(.007)\end{array}$ & $\begin{array}{l}.022 \\
(.005)\end{array}$ & $\begin{array}{l}.050 \\
(.004)\end{array}$ \\
\hline Age $^{2} / 100$ & $\begin{array}{l}-.059 \\
(.004)\end{array}$ & $\begin{array}{l}-.060 \\
(.003)\end{array}$ & $\begin{array}{l}-.065 \\
(.009)\end{array}$ & $\begin{array}{l}-.043 \\
(.008)\end{array}$ & $\begin{array}{l}-.026 \\
(.006)\end{array}$ & $\begin{array}{l}-.058 \\
(.006)\end{array}$ \\
\hline $\begin{array}{l}\mathrm{R}^{2} \\
\mathrm{~N}\end{array}$ & $\begin{array}{c}.29 \\
20053\end{array}$ & $\begin{array}{c}.30 \\
22248\end{array}$ & $\begin{array}{l}.07 \\
7383\end{array}$ & $\begin{array}{c}.11 \\
10583\end{array}$ & $\begin{array}{l}.08 \\
7123\end{array}$ & $\begin{array}{c}.14 \\
10267\end{array}$ \\
\hline$\hat{\sigma}_{\epsilon}^{2}$ & .174 & .140 & .324 & .342 & .312 & .327 \\
\hline
\end{tabular}




\section{Appendix Table C2 (continued)}

${ }^{8}$ The employment equations are linear probability models for working or not working over the income year. The weeks equatlons use the logarithm of annual weeks as the dependent varlable, and are estimated using the sample of full-time workers who worked for at leeast one week during the year. The wage equations use the logarithm of annual earnings divided by annual weeks worked as the dependent variable, and use only full-time workers.

${ }^{b}$ All regressions include four (five in 1987) region dummles and the number of nonearners in the famlly as independent varlables. The employment and hours regressions also include the spouse's education and age variables as independent variables. 